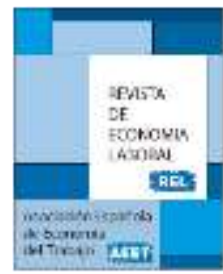

\title{
WORK SCHEDULES AND PARENTS' TIME ALLOCATION
}

\author{
Laura Bengoa and Arantza Ugidos ${ }^{1}$ \\ University of the Basque Country UPV/EHU
}

Received December 2017; Accepted January 2018

\begin{abstract}
This study uses most recent Spanish time-use data (2009-2010) to study the effect that different work schedules have in the time spent on activities with the different family members. We estimate a double-hurdle model that allows us to take into account the clustering of a large proportion of observations at zero and deal with both the incidence and the intensity of spending time in a particular time use. Our results show that the split-shift has a negative association with family time and parent-child time, two activities that improve the relationship among family members and improve the wellbeing of children. Parents engage more in parent-child activities when their spouse is working the split shift or evening shift. The negative effect that working an evening or split shift has on parentchild time is smaller for women than for men. The opposite is observed with non-family time.
\end{abstract}

Key Words: Time-use, standard work schedule, split-shift, family-time, parent-child time, work-family balance, double-hurdle model

Classification JEL: J22

${ }^{1}$ Grant ECO2015-64467-R (MINECO/FEDER) is gratefully acknowledged.

(C) Revista de Economía Laboral 


\section{Resumen}

Este trabajo analiza la Encuesta Española de Empleo del Tiempo más reciente (2009-2010) para estudiar el efecto que tienen diferentes tipos de jornada diaria de trabajo en el tiempo que se pasa con los diferentes miembros de la familia. Estimamos un modelo de doble valla que nos permite tener en cuenta el agrupamiento de una gran proporción de observaciones en cero y analizar simultáneamente tanto la incidencia como la intensidad del tiempo familiar. Nuestros resultados muestran una relación negativa entre trabajar a jornada partida y el tiempo que se pasa en familia y con los hijos, dos actividades que mejoran la relación entre los miembros de la familia y mejoran el bienestar de los niños. Los padres pasan más tiempo con sus hijos cuando su cónyuge tiene un empleo a jornada partida o trabaja de tarde. El efecto negativo de la jornada partida o de trabajar de tarde es menor para las mujeres que para los hombres. Lo contrario se observa con el tiempo personal no familiar.

Palabras claves: Uso del tiempo, jornada de trabajo standard, jornada partida, tiempo en familia, tiempo entre padres e hijos, conciliación laboral y familiar, modelo de doble valla Clasificación JEL: J22 


\section{Introduction}

It has not been that long since women started participating in the labor market in a massive way. With the increasing participation of women in paid work new concerns arose, as for instance, how will individuals reconcile family time and work time. When women rarely participated in the labor market traditional roles made women the ones looking after the house and the children, while the husband was the one earning the money to support the family in the working place. With the entry of women in the labor force after the World War II and mainly since the 1970's another form of organization within household is necessary as traditional roles are no longer adequate for the new circumstances (Jacob and Gerson, 2005).

In this paper we are going to study how spouses coordinate the time they spend with each other and with their children depending on their work schedules. Parent's amount of paid work is likely to influence family life, but their work schedules can also critically interfere with family activities. Presser (2003) suggested that working non-standard hours is generally detrimental to family life. There is not a clear definition of what a non-standard work schedule is, but most studies consider working during weekends or weekdays after 5-6 p.m. as a non-standard work schedule. We define a standard work schedule as that in which the individual works at least three hours between 7:00 and 16:00 and less than 2 hours from 16:00 till 24:00.

Our main goal is to study the effect that different work schedules have on the amount of time that each parent spends in parent-child activities, in activities for the whole family where the partner and at least one of the children are involved, in activities for the couple, and in activities by herself (or himself) or with other people outside the household members.

Parents should be motivated in engaging in family activities as it plays a critical role in improving the family solidarity and relations (Bianchi et al., 2006; Dew, 2009). To get involve in family activities both parents and at least one child are needed. This means that there has to be synchronization in the schedules of, at least, three members of the family. While parents may have different work schedules, children schedule is quite fixed when they are at school age. In the first years of education (kindergarten and primary education) most school schedules finish at 4 p.m. or 5 p.m. After the school hours children might have out-of-school activities that normally finish between 5-6 p.m. This schedule matches 
quite well the standard work shift but it could be a problem when the parents have an evening or split shift. Most European schools have continuous school day that finishes between two thirty and three o'clock. These school schedules are each day more common in Spain ${ }^{2}$ and could make even more difficult for parents to spend time with their children when they are working even a standard shift. We would expect split shift and evening shift workers and their spouses to spend less time in family activities than do standard shift workers and their spouses

The motivation to engage in parent-child time when the other partner is not present should be also high for parents as it promotes close parent-child relations (Roeters et al., 2010) and child development. This parent-child time improves kids' physical and intellectual ability ( $\mathrm{Li}$ et al., 2014). For engaging in parent-child activities only one of the parents is needed, therefore coordination among spouses work schedules is not necessary. But, once again, at least one of the parents needs to be available when the children are not in school or in extracurricular activities. We could expect that some parents will try to coordinate with each other in order not to leave children unattended, that is, that the children are with one of them. In this case they would decide that, at least one of them, should finish earlier the work day if possible. For this reason it would be interesting to study how the spouse work schedule affects the time the individual spends with their children, as we would expect that if the spouse is working an evening or split shift then the individual will be spending more time in activities with their children. We would also expect split and evening shift workers spend less time in parent-children activities than do standard shift workers.

The time that both spouses spend doing activities together and without the children (couple time) is also important. Psychologists point out the importance of engaging on activities with your spouse as this would improve the relationship among the spouses, which would also improve the family life ( $\mathrm{Li}$ et al., 2014). These couple activities are normally done when kids are not present or when they are sleeping. If both parents work an evening shift then they could engage in couple activities in the morning, but it is unusual that neither of the spouses works in the morning. Therefore, we would expect that working an evening shift decreases the time spent in couple activities.

\footnotetext{
${ }^{2}$ In Spain the continuous school day schedule was only available in high school. In the last 5 years it has increased significantly in centres of infant and primary education in 9 out of 17 autonomous communities, according to data from the Department of Education of the different autonomous communities. (Sanmartin, 2014)
} 
Regarding the last time-use considered, non-family time, it is also important for the whole family as it gives the individual time to focus on their hobbies and build social relations outside the household. Non-family leisure time improves the individual well-being, minimizing the stress and health risk (Mattingly and Sayer 2006). For engaging in oneself time, you do not need to coordinate your schedule with that of any other family member, so it is more frequent to engage in this type of activities when the other family members are at school or working. Therefore we expect that individuals working the evening shift and their spouses will spend more non-family time as they are free when their spouses are busy, assuming that the spouse is working in the morning.

Considering the importance of engaging in this four time uses, as we have explained before, it is important to make easier the work-family balance mainly after the observed large increase in female labor force participation rates narrowing the male-female gap (Figure 1). Making work schedules more compatible with school schedules might be a way of facilitating the conciliation of the labor and family life. In fact, one of the issues during the previous political campaign in Spain was the benefits that ending the working day before six o'clock could have on this conciliation. Providing evidence of the negative effects of working later than 6 p.m. on the time spent with the family could give the motives to undertake the adequate policy changes to improve the work-family balance. This policy changes might have a positive effect on the decision of having more children per women, as in the last 40 years there has been an important decrease in the fertility rate of western countries.

There have been many researchers that studied the time allocation. In particular, there have been researchers that have studied the relation among different work schedules and the time spent with the different members of the household (Lesnard, 2008; Wight et al., 2008; Gracia and Kalmijn, 2016). We will review the literature on time allocation and state our contribution in section 2 . Section 3 describes the data, section 4 the estimation method and section 5 shows the empirical results. Main conclusions are presented in section 6 . 
Figure 1: Activity rate (\%) of women and men 2002-2016

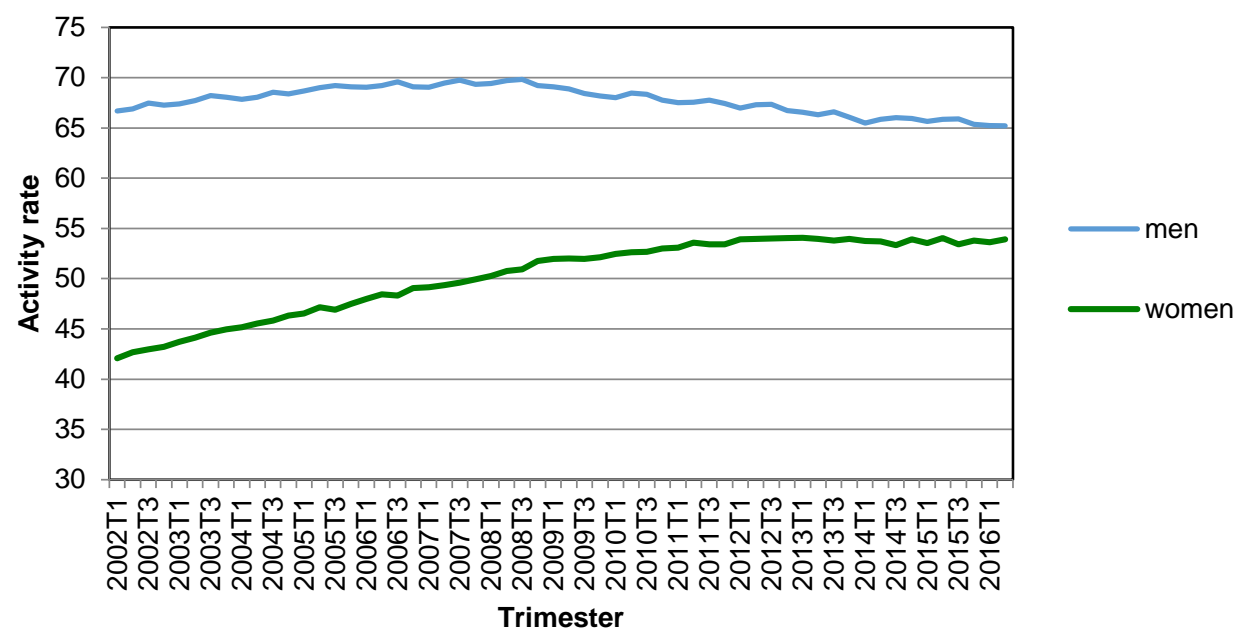

Source: Own elaboration from Labor Force Survey (Spanish Institute of Statistics).

\section{Previous Literature}

In this paper we study how individuals allocate their time focusing on with whom they spend this time ${ }^{3}$. One of the first people to study the allocation of time from an economic perspective was Gary Becker (1965). Becker along with Jacob Mincer was one of the pioneers of the New Home Economics, an approach that studies family decisions considering the household, and not the individual, as the unit of analysis. According to this approach parents may prefer to have fewer children of higher quality by devoting higher resources to them. This will also include spending more time with each child.

One of the main assumptions of their approach is that the households try to maximize their utility with commodities. These commodities are produced using time and market goods. Each household has their own time and budget constraints. Households where both parents work could have a larger budget but their leisure time will be more limited so they may prefer to consume more market goods (for example: having lunch at a restaurant) instead of time consuming commodities produced at home. When one of the spouses does not work,

\footnotetext{
${ }^{3}$ We do not analyze the activities they carry out.
} 
they could decide to increase the consumption of time consuming commodities (for example: eating homemade meals), and decrease the consumption of market goods as their budget is more limited. Depending on the time and budget constraints of each household they would decide how to arrange their consumption between market good and time consuming commodities.

Another concept discussed by the New Home Economics is the comparative advantage. A spouse may be more productive in certain types of housework than his/her partner. Therefore, each spouse may specialize in those household chores in which he/she is more productive. They may substitute time by market goods for the production of other commodities where they are not as productive. This idea considers that housework time may be gendered, as men and women areas of expertise may be different.

Gimenez-Nadal and Molina (2013) pointed out that one of the main questions that many researchers have tried to answer inside the approach of the New Home Economics is how the members of a household decide to allocate their resources (time and money). There are different economic approaches that have tried to answer this question. One of these approaches is a model that sees the household as a place of conflict and cooperation, where intra-household bargaining models and collective models are found. The second approach is based on competitive marriage market models. These models' main assumption is that prospective spouses, in the marriage market, can make binding agreements about allocation of time in marriage. All the previous models incorporate the issue that joint family decisions can be derived from sometimes divergent interests of males and females.

In this paper we focus our study on analyzing how the partners' work schedules affect the amount of time they decide to spend with other members of the household that is, their time allocation. For spending time with your family there have to be coordination among the household members, so it is easier to do so when parents and children have leisure time at the same hours of the day. Working nonstandard hours is generally detrimental to family life (Presser, 2003). How non-standard work schedule is defined differ from one study to another. Presser (2003) defines it as working outside 9 a.m. to 5 p.m. time interval. Li et al. (2014) define a non-standard work schedule as that which implies to work before 6 a.m. or after 6 p.m. They include in this category evening shift, night shift, split shift, working in a rotating shift (i.e. alternating between day, evening or night shifts, but on a fixed schedule), irregular hours, and 
regular weekend work. Presser (2003) points out that nowadays many countries have service economies, what he calls the " $24 / 7$ economy". This type of economies comes with the idea that there exists demand every day of the week at any hour, what raises the need of non-standard workschedules. This labor market trend has raised concern about its potential impact on children's well-being (Li et al., 2014).

To date only three studies, that we are aware of, have analyzed how parents' work schedules are related to multiple daily activities. Lesnard (2008) used French data to find out that working nonstandard work schedules is negatively associated with the time that individuals spend with their children, their spouse, or with their whole family. He also found that parental care time was more responsive to the spouse's work schedule among mothers than fathers. Wight et al. (2008) using data from the U.S. also found that nonstandard work schedules affected negatively to the time that individuals spent with their spouses, but they found positive relationship among nonstandard work schedules and time spent with children. Wight et al. (2008) only consider the work schedule of the individual under study and not the work schedule of the partner. Finally, Gracia and Kalmijn (2016), using 2002-03 Time Use Spanish data set, found out that the split shift had a strong negative effect on family time and on time spent with children. They also found that the evening shift had a negative effect on family and couple time, but not on time spent with children. They also found some differences among genders. They found that mothers spent much more time than men with children for all work schedule categories, and that women were more responsive to the spouse's work schedule.

We contribute to the literature by using the most recent Spanish time-use data set that has been improved relative to the previous one used by Gracia and Kalmijn (2016). The STUS 2002-2003 does not allow separating the activities that the individuals do with their couple from those that they do with their children above 9 years old. For this reason, they only considered those families with children under 10 years old, dropping the families where at least one child above the age of 9 was present. In the newest version of the data we can divide the time that the individual spends with the partner from the time spent with the kids older than 9 years. This has allowed us to include all the families with at least one child under 18 years old in our sample. We believe this has improved the results found as they could be expanded to a larger part of the population as they are less restricted. The previous results were only for families where very young children were present, whereas now we 
have found evidence for families with children of all ages.

We also differ from Gracia and Kalmijn (2016) in that we have considered that those individuals working 0 hours the reference day can be divided into two different groups, unemployed and non- working, as we think their characteristics are different and they organized their time differently. Gracia and Kalmijn (2016) put those people together in the same category (non-employed).

Finally, we contribute by estimating a double hurdle model that allows us to take into account the clustering of a large proportion of observations at zero and deal with both the incidence and the intensity of spending time in a particular time use or activity. That is, this method estimates the effect of the control variables (i.e. work schedules) on the time spent together having into account simultaneously the probability of participating in the activity (spending time together in our case). Else, unlike the Tobit model, the double hurdle model allows for different factors affecting the incidence and the intensity decisions. The double hurdle model has been widely used in the study of household expenditure; however, it has not been used for studying the allocation of individuals' time.

\section{Data, Variables and Descriptive Analysis}

We use the Spanish Time Use Survey (STUS) collected in 20092010 by the Spanish Institute of Statistics to study how spouses' work schedules affect the amount of time they decide to spend with other members of the household, that is, their time allocation. The Time Use surveys are considered the best statistical source for analyzing individuals' daily activities (Gershuny, 2003). These surveys have a diary of activities where individuals report all the activities they have done for a reference period. In the case of Spain this reference period is of 24 hours. In this diary, individuals from a household who are 10 years old or older will report what they have done during 24 hours, dividing the day in 144 slots of 10 minutes each. The reported information starts at 6 am and ends the next day at $6 \mathrm{am}$. In this diary individuals will report not only the activity that they are doing but also with whom they are at that moment, that is, if they are alone, with their partner, with their parents, with a child younger than 10 years old, with other member of the family, or with other acquaintance. Therefore the 24 hours are divided in time 
uses defined according to with whom the individual is at that time.

Time-use diary data sets are particularly advantageous over other surveys because they are less sensitive to the recall and aggregation bias that is associated with broader survey questions capturing average time spent (Bianchi et al. 2006). They are less sensitive to the recall bias due to the shorter recall period. Also, they are less susceptible to aggregation bias because respondents report all activities sequentially and thus account for the full 1440 minutes in the day (Kalenkoski et al. 2011). Finally, time diaries provide information on non-market activities that is generally unavailable in labor force surveys (Burda et al. 2012).

\subsection{Subsample}

The STUS is a nationally representative data set that contains 19,295 diaries from 25,895 people living in 9,541 households. We are interested in analyzing how spouses' work schedules are associated with family, partner, parent-child, and non-family time. Therefore, our target group is households of heterosexual couples without other adults in the household ( $\mathrm{N}=3093$ households), where the two spouses are between ages 25 and $59(\mathrm{~N}=2899)$ and have at least one child younger than 18 years old $(\mathrm{N}=2483)$. We dropped 374 households in which one of the spouse did not report a diary of activities $(\mathrm{N}=2109)$. We also dropped from the sample the couples whose reference day was during the weekend, as most people engage in paid work activities during week days, and we want to have a homogeneous sample in order to study the effect of different work schedules on time allocation $(\mathrm{N}=1290)$. Finally, we dropped households with incomplete work and demographic information which left us with a final sample of 1,201 couples.

We consider households without other adults apart from the parents. If there were other adults, for example grandparents, the arrangements of the family could differ as the grandparent might have a more active role in the family. They could cook dinner or do some of the housework and childcare. This may have an effect on the time spent with the family members by the spouses. We also restrict to heterosexuals couples because we do a gender study. 


\subsection{Variables}

\subsubsection{Dependent variable: Time-use}

In particular, we are interested in studying how different work schedules affect with whom individuals (parents) spend their nonworking hours (our time-use variable). To carry out our goal, we divide time-use into 4 categories: family time (partner and children at the same time), parent-child time (minutes per day spent only with their children), partner time (minutes per day spent only with their partner) and non-family time (minutes per day spent without family members). We next define in more detail these 4 time-uses.

\section{Family time}

Family time is that spent with the partner and at least one of the children at the same time, what means that at least three different household members' schedules have to be synchronizing for engaging in this type of time.

\section{Parent-child time}

This time use considers the time spent by individuals with their children under 10 years old. We believe that parents work schedules have a real effect on this age group. The time spent with older children does not depend that much on the time that parents have available but also on the time available and the decisions made by the children. If the child decides to go out with his/her friends instead of staying at home and doing an activity with his/her parents, this has nothing to do with the work schedule of the parents.

\section{Partner time}

It is defined as the time that the individual spends with his/her spouse, by themselves, without any of their children. It will be easier for couples to engage in this kind of activities while their kids are not at home or they are sleeping.

\section{Non-family time}

This refers to the time that the individual spends without any member of the household, that is, the time spent by himself/herself or with friends. We would expect that if a spouse is not working while the other members of the household are engaged in work or at school, his/her 
non-family time will increase. This is the only time use where no synchronization of family members schedules is needed.

\subsubsection{Key explanatory variable: Work schedule}

Our main control variable is the individuals' work schedule. We are interested in analyzing the effect that each work schedule has on the minutes per day that an individual spends in each of the time use categories defined above. The work schedules are mutually exclusive. We also include the non-employed variable to capture the effect of parents that were not engage in any paid work.

In Figure 2 we can see the percentage of men and women engaged in paid work at each hour of the day. This figure has been elaborated from the STUS of 2009-2010 using the information reported for the 7th day of the weekly paid work schedule file. In the weekly paid work schedule file all working individuals reported in slots of 15 minutes if they were working or not during the whole week. The seventh day of the weekly paid work schedule always coincides with the reference day in which individuals have to fill in the activity diary. In the figure, we can clearly observe two peaks, one in the morning from 8 o'clock till around half past one and the other one in the afternoon from three o'clock until six thirty. This shows evidence of the split shift where working hours are divided between the morning and the afternoon. As shown by Amuedo-Dorantes and de la Rica (2009), other European countries working days show only one peak where a reduction could be seen during the lunch break, but this reduction is shorter and less acute. Consequently we could say that the split shift is a peculiarity of the Spanish case. Moreover, most European countries finish their working days earlier than Spain, what makes easier to balance the family-work life. 
Figure 2: Percentage of men and women engaged in paid work by hour of the day

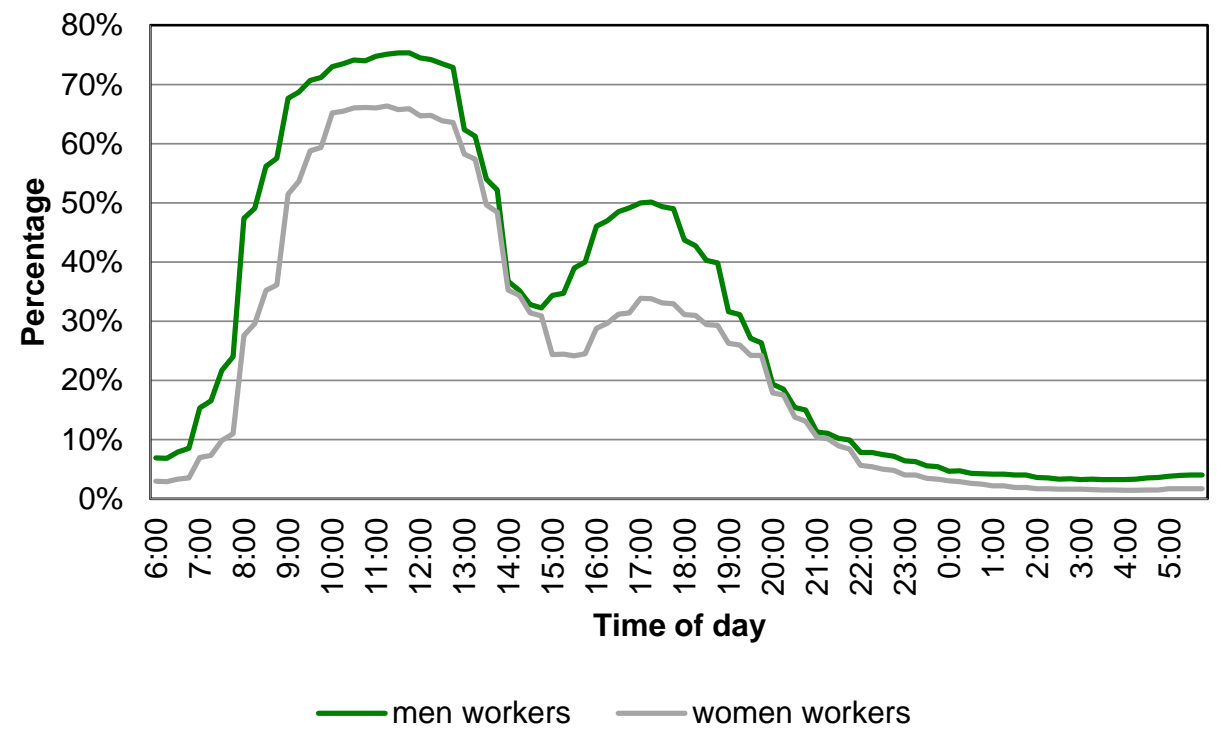

Source: Own elaboration from STUS 2009-2010 data

To define the different work schedules we have follow Gracia and Kalmijn' (2016), but with some modifications to get closer to the non-standard work schedules definition of other papers in the literature. Gracia and Kalmijn (2016) consider that an individual has to finish the working day before $8 \mathrm{p} . \mathrm{m}$. to be included in the standard shift. Bearing in mind Li et al. (2013) and Amuedo and de la Rica (2009) studies we have redefined the work schedules and classify a person that works after 6 p.m. as working a non-standard schedule.

Furthermore, we have considered two different groups of people working zero hours the reference day, those unemployed and those employed but that did not work that day (non-working), as we think their characteristics are different and they organized their time differently. We have people that are unemployed in the reference day, and people who being employed did not perform any work activity in the reference day. Gracia and Kalmijn (2016) put those people together in the same category. 
Standard shift

In this category we will include a typical work schedule from 8:00 till 17:00. The individual will be working while the kid is at school so this work schedule interferes to a lesser extent with the family duties. We will also consider that an individual is part of this category when he/she works 3 or more hours from 7:00 till 16:00 and less than 2 hours from 16:00 till 24:00. With this definition, people included in this category finish their work before 6 p.m.

Evening shift

In this shift we will include people that do not work during the morning (before 14:00) and that work 3 hours or more between four in the afternoon and midnight. Therefore a person that starts at four should be working at least until 7 to be considered part of this work schedules. In Spain most kids stay in school until 4 or 5 in the afternoon so a parent that leaves work at 7 p.m. could be missing some valuable time with their kids.

\section{Split shift}

This category should include people that work during the morning and the afternoon, with a long lunch break. This break makes their working hours to expand during the day, and they will be still working when their kids have finished school. We are going to define this work schedule as individuals that work 2 or more hours from 7:00 till 14:00 and that work also 2 or more hours from 16:00 till midnight. With this definition all of them will be arriving home after 6 o'clock, when we would expect their children to be already at home.

\section{Nonemployed}

We have divided the non-employed people into two categories as, in our opinion, both categories may have very different characteristics.

- Unemployed: people that report that they were unemployed when the survey was conducted. Therefore they report 0 hours of work on the reference day.

- Not working: People who report that they are employed but in the reference day reported zero hours of work. They could be on holidays, sick, or they could have a free day. It could also be 
people that work during the weekends or very few hours per week so they have not worked the reference day ${ }^{4}$.

\subsubsection{Other control variables}

We include as explanatory variables some variables that capture variations among individuals opportunity cost, lifestyles, and demographic characteristics. Even though they are not our main aim, it is important to include them in order to not overestimate the effect of our principal independent variable, the work schedules.

- Hours of work: total hours that the individual works the reference day. To capture the effect of this variable we include three dummy variables: part-time, when the individual has worked less than 6 hours, but more than 0; overwork, when the individual has worked more than 10 hours. The last category, full-time will include the individuals that work between 6 and 10 hours.

- Education: we include four different dummy variables to cover the highest level of education that the individuals have reached. Primary education will include people who do not know how to write or read, people who have not finished their primary education and people with primary education as their highest education level. The second category, low secondary education, will include people who have reached secondary education of first level (ESO or equivalent) as their highest level of education. The third category, high secondary education, will include people that have finished high school (A level) or vocational training of middle or high level ("grado medio" or "grado superior"). The last category would be college, which will include people with a university degree, a master or a doctorate.

- Outsourcing domestic work: a dummy variable that takes value one when there is domestic help in the family.

\footnotetext{
${ }^{4}$ Remember that we have dropped from the sample people which reference day was during the weekend. However, we include people whose reference day is during the week, and they may work during the weekends
} 
- Number of children: We include four different variables in this category. In the quantity decision equation we include a dummy variable that takes value 1 when there is a child in the family below 2 years old and two continuous variables indicating the number of children younger than 9 years old in the family and the number of children between 10 and 18 years old. In the participation equation we include a dummy variable that takes value 1 when there is a child in the family under 10 years of age

- Married: dummy variable that takes value 1 when the couple is married and value 0 when the couple is not married.

- Age: continuous variable that stands for the age of each individual.

\subsection{Descriptive analysis}

Table 1 shows the summary statistics. Regarding our dependent variable, the time-use, we observe that men report that they spend more minutes per day than women in family time and couple time. Men report to spend 6 minutes more per day, on average, than women on family time, and 8 minutes more than women, on average, on couple time. For these two time uses men and women have to be together, so the reported minutes per day should be the same for men and women. From these results we could conclude that men overestimate the time spent with the family or the partner compared to women. On the other hand, women report higher values for time spent with children and on non-family time than men. Women spend 94 minutes more per day, on average, with children under 10 years old, and 24 minutes more per day, on average, with older children. Regarding non-family time, women spent 16 minutes per day more than men on average in this time use ${ }^{5}$.

\footnotetext{
5 The means given for the time uses only consider the individuals that report more than 0 minutes per day on the studied time use. We do not consider the people that report spending 0 minutes per day on the time use. There are differences between men and women on the people that have report spending time in each time use. For example $51.37 \%$ of women have reported spending some time with children under 10 years old whereas only $31.39 \%$ of men have reported values greater than zero for that time use. All the percentage of individuals reporting spending time in each time use can be found in table 1.
} 
Table 1: Summary Statistics: Means and SD for the whole sample and only for when both parents are working

\begin{tabular}{|c|c|c|c|c|c|c|}
\hline & \multicolumn{3}{|c|}{ Women } & \multicolumn{3}{|c|}{ Men } \\
\hline & $\%>0 \mathrm{~min}$ & Mean & $\mathrm{SD}$ & $\%>0 \mathrm{~min}$ & Mean & $\mathrm{SD}$ \\
\hline Family time (minutes per day)* & 75.10 & 140.95 & 4.302 & 76.01 & 146.94 & 4.302 \\
\hline Time with children* & 10.90 & 110.83 & 8.812 & 4.74 & 67.36 & 8.812 \\
\hline Time only with kids $\leq 9$ years* & 51.37 & 205.62 & 6.058 & 31.39 & 112.04 & 6.058 \\
\hline $\begin{array}{l}\text { Time only with old kids }>9 \\
\text { years* }\end{array}$ & 30.64 & 110.10 & 5.137 & 20.15 & 85.99 & 5.137 \\
\hline Time with partner* & 66.52 & 104.54 & 3.354 & 66.28 & 112.81 & 3.354 \\
\hline Non family leisure time* & 85.59 & 184.01 & 4.607 & 78.60 & 167.52 & 4.607 \\
\hline Part time $(<6 \text { hours })^{* *}$ & - & 0.274 & - & - & 0.047 & - \\
\hline Overwork (> 10 hours $) * *$ & - & 0.028 & - & - & 0.191 & - \\
\hline Full time ${ }^{* *}$ & - & 0.698 & - & - & 0.762 & - \\
\hline Standard work schedule & - & 0.328 & - & - & 0.281 & - \\
\hline Evening work schedule & - & 0.047 & - & - & 0.045 & - \\
\hline Split work schedule & - & 0.118 & - & - & 0.400 & - \\
\hline Unemployed & - & 0.376 & - & - & 0.144 & - \\
\hline No working & - & 0.131 & - & - & 0.130 & - \\
\hline Primary education & - & 0.157 & - & - & 0.177 & - \\
\hline Low secondary & - & 0.223 & - & - & 0.235 & - \\
\hline High secondary & - & 0.327 & - & - & 0.359 & - \\
\hline College & - & 0.292 & - & - & 0.227 & - \\
\hline Domestic service & - & 0.116 & - & - & 0.116 & - \\
\hline Child $\leq 2$ years $(\%)$ & - & 0.238 & - & - & 0.238 & - \\
\hline Number children & - & 1.810 & 0.773 & - & 1.810 & 0.773 \\
\hline Num. children $\leq 9$ years & - & 0.875 & 0.844 & - & 0.875 & 0.844 \\
\hline Num. children $10-18$ years & - & 0.737 & 0.774 & - & 0.737 & 0.774 \\
\hline Married & - & 0.903 & 0.238 & - & 0.903 & 0.238 \\
\hline Age & - & 40.25 & 6.48 & - & 42.58 & 6.96 \\
\hline $\mathrm{N}$ & & 1,201 & & & 1,201 & \\
\hline
\end{tabular}

Source: Data from STUS 2009-2010.

*In the first column of each sex, $\%>0 \mathrm{~min}$, we show the percentage of individuals that have reported more than 0 minutes per day on each time use. In the second column the mean is calculated over the subsample of individuals who reported more than zero minutes.

**The mean is calculated only considering the individuals who work the reference day.

Regarding the explanatory variable of work schedules we have a very different distribution for men and women. The most common work schedule for women is the standard shift; almost $33 \%$ of the sample is included in this work schedule. Whereas only $12 \%$ work split shift and $4.7 \%$ work the evening shift. For men the most common work schedule 
is the split shift. Around $40 \%$ of men in our sample are working this shift. There are $28 \%$ of the men in our sample working a standard shift and only $4.5 \%$ are in an evening shift. There is also a big difference in the non-employed categories. Whereas the people that report not working is similar for both gender, around $13 \%$, women unemployment rate is much higher than men. Whereas only $14 \%$ of men in the sample are unemployed, $38 \%$ of women reported an unemployment status.

Concerning the number of hours worked among those individuals reporting a positive number of hours, $27 \%$ of women and $4.7 \%$ of men work less than 6 hours. Only $2.8 \%$ of women but $19 \%$ of men work more than 10 hours. In our sample men have longer working days than women, on average. In society, normally women are the ones reducing their working days when having children. This could help to explain the results reported on our sample regarding the distribution among the three dummy variables controlling for total work time for men and women.

In our sample women are more educated than men as $29 \%$ have college or a higher level of education, while only $23 \%$ of men are in this circumstance. However the most reported level of education for both genders is high school, reported by $33 \%$ of women and $36 \%$ of men.

For the household control variables, $12 \%$ of our sample outsourced domestic labor. In almost $24 \%$ of the households there is a child under 2 years of age. The average number of children is 1.81 , the average number of children younger than 10 years old is 0.87 and the average number of children older than 9 is 0.74 . Finally, in our sample men are 2.3 years older than women, on average.

\section{Estimation Method}

Time use survey data provides a diary of activities in which each individual writes down what activity has carried out throughout the reference period (24 hours in the Spanish case) and, especially important for our study, with whom they performs that activity.

There is in the literature a discussion about what estimation method should be used when analyzing data from Time Use Surveys. This data has a characteristic that makes them special. This 
characteristic is the large number of zeros that the individuals report in their diaries of activities. Many individuals report that they are not doing a certain activity in the survey day, however, that does not mean that those individuals do not perform that particular activity. They may carry out that activity other day of the week. In this case we call those zeros "false zeros". The false zeros appeared when individuals report that they are spending zero minutes in a certain time-use or activity in their diaries of activities, but, in reality, they do perform this activity or spend some minutes per day in that time-use but not in the reference day. If we would expand the reference period, for example instead of analyzing only one day we consider a 48 hours period, these false zeros would tend to disappear. This was demonstrated by Foster and Kalenkosky (2013) with data from Australia where the survey is done for a 48 hours window length. Else, in our sample we are considering cohabiting couples that live with their children, so it would be really difficult for an individual not to spend any time with his/her spouse, with his/her kids, or even get some time to himself/herself. Therefore, it is very likely that many of the reported zeros are not real zeros but false zeros.

We know that when we face censored data, with a lot of zeros for partially known observations, the Tobit model is usually applied since was originally developed to analyze censored dependent variables. However, if the zeros do not indicate censoring, the Tobit model would not be appropriate (Stewart, 2013). A more appropriate model would be an extension that takes into account the incidence and the intensity by estimating simultaneously two equations, the Double Hurdle Model (Cragg, 1971). The first equation would estimate the probability of the incidence (the individual decide to participate or not, for instance, decide to spend time with children) and a second equation would estimate the conditional intensity (how much time do the individuals spent after having decided to participate) using the individuals that decide to participate (in the example, using the individuals who have decided to spend time with the children).

We have to understand that an individual could decide to participate, but then decide to spend zero minutes in the time use (activity). This implies that we do not divide the participants and the non-participants on the basis of the observed amount of time devoted by individuals to the activity. The decision of participating in the process is unobserved. 
The double hurdle model can be specified as follows (Blundell and Meghir, 1987, Newman et al., 2003),

$$
\begin{aligned}
& y_{i 1}^{*}=w_{\mathrm{i}} \alpha+u_{\mathrm{i}} \quad \text { Participation decision } \\
& y_{i 2}^{*}=x_{\mathrm{i}} \beta+v_{\mathrm{i}} \quad \text { Quantity decision (minutes per day) } \\
& \mathrm{y}_{\mathrm{i}}=\left\{\begin{array}{lr}
\mathrm{x}_{\mathrm{i}} \beta+v_{\mathrm{i}} & \text { if } y_{i 1}^{*}>0 \text { and } y_{i 2}^{*}>0 \\
0 & \text { otherwise }
\end{array}\right.
\end{aligned}
$$

Where $y_{i 1}^{*}$ is a latent endogenous variable representing an individual or household participation decision, $y_{i 2}^{*}$ is a latent endogenous variable representing an individual or households quantity decision, $y_{i}$ is the observed dependent variable (minutes per day spent in each time use), $w_{\mathrm{i}}$ is a set of individual charactheristics explaining the participation decision, $x_{i}$ stands for variables explaining the quantity decision and $u_{\mathrm{i}}$ and $v_{\mathrm{i}}$ are independent, homoscedastic, normally distributed error terms.

The double hurdle model is estimated using maximum likelihood techniques with the log likelihood given as follows,

$\log (\mathrm{L})=\sum \ln \left[1-\Phi\left(\mathrm{w}_{\mathrm{i}} \alpha\right) \Phi\left(\frac{\mathrm{x}_{\mathrm{i}} \beta}{\sigma_{i}}\right)\right]+\sum \ln \left[\Phi\left(\mathrm{w}_{\mathrm{i}} \alpha\right) \frac{1}{\sigma_{i}} \phi\left(\frac{\mathrm{y}_{\mathrm{i}}-\mathrm{x}_{\mathrm{i}} \beta}{\sigma_{i}}\right)\right]$

The standard Tobit model is a nested version of the Cragg model when $\mathrm{w}_{\mathrm{i}} \alpha$ is equal to 1 (i.e. the log likelihood of the Tobit model equals that of the Cragg model when there is no participation equation). Thus the Cragg model is effectively a Tobit model that allows for estimates of the participation equation to be made separately from those of the quantity equation, and allows for different factors affecting the participation and the quantity decisions.

The double hurdle model has been widely used in the study of household expenditure, however, it has not been used for studying the allocation of individual's time. The application of the double hurdle model to the STUS in this paper thus represents a significant addition to the existing literature in the area.

The double hurdle model can be compared with Heckman's sample selection models. However there is a very important difference between these two methods. Heckman assumes that when we observe a zero observation, then, that individual is a non-participant, while with the double hurdle, an individual who reports to spend zero minutes in 
an activity does not have to be a non-participant. Zero minutes reported could be due to two different situations, either non-participation or participation but no minutes spent in the time use. The Cragg model can be thought as a flexible version of both the Tobit model and Heckman selection model.

\section{Empirical Results}

Table 2 shows the estimation results. First, we show the quantity decision results, that is, the estimated effect of the different explanatory variables on the amount of time spent in each time-use. Then we show the participation decision results, that is, the effect that control variables have on the decision of participating or not in each time-use.

With respect to the first step of the decision, participating or not, we have studied the effect of having children under 9 years old, having different work schedules, the different levels of education and if the couple is married or not.

Individuals living in a household where children under 9 years old are present will be more likely to participate in family time and children time and less likely to participate in non-family time. Regarding the work schedules ${ }^{6}$, individuals working an evening shift will be less likely to participate in family time. Women will be more likely to participate in children time, while fathers' participation in this time use is not going to be influenced by the evening shift. Individuals working a split shift will be less likely to participate in partner time. Men will also be less likely to participate in children time and nonleisure family time, whereas mothers will be less likely to participate in family time. As to education level, it has a significant positive effect on the participation in family time, children time and partner time, but it does not affect participation in non-family time. We observe an increase in the chance to participate in family time once achieved the high secondary education. In the case of children time, women will be more likely to participate in this time-use when having college education, whereas fathers' participation will increase with each education level.

\footnotetext{
${ }^{6}$ Given that work schedule is not really a choice by the employee but given by the employer, we do not think that the effect of working schedules may reflect special characteristics of workers with different work-schedules.
} 
Table 2: Double Hurdle model estimation results.

\begin{tabular}{|c|c|c|c|c|c|c|c|c|}
\hline & \multicolumn{2}{|c|}{ Family time } & \multicolumn{2}{|c|}{ Children time } & \multicolumn{2}{|c|}{ Partner time } & \multicolumn{2}{|c|}{ Non family time } \\
\hline & Women & Men & Women & Men & Women & Men & Women & Men \\
\hline \multicolumn{9}{|c|}{ Quantity decision } \\
\hline Own work schedule & & & & & & & & \\
\hline Unemployed & $\begin{array}{c}98.51^{* * *} \\
(32.35)\end{array}$ & $\begin{array}{c}97.67 * * * \\
(31.06)\end{array}$ & $\begin{array}{c}221.5^{* * *} \\
(23.53)\end{array}$ & $\begin{array}{c}142.4^{* * *} \\
(35.14)\end{array}$ & $\begin{array}{c}98.91^{* *} \\
(41.26)\end{array}$ & $\begin{array}{c}183.9 * * * \\
(42.82)\end{array}$ & $\begin{array}{c}278.1^{* * *} \\
(26.16)\end{array}$ & $\begin{array}{c}337.4^{* * * *} \\
(35.42)\end{array}$ \\
\hline No working & $\begin{array}{c}159.0^{* * * *} \\
(36.31)\end{array}$ & $\begin{array}{c}184.7 * * * * \\
(30.67)\end{array}$ & $\begin{array}{c}236.2^{* * *} \\
(25.85)\end{array}$ & $\begin{array}{c}133.7^{* * * *} \\
(37.30)\end{array}$ & $\begin{array}{l}79.28^{*} \\
(47.12)\end{array}$ & $\begin{array}{c}178.4^{* * * *} \\
(41.28)\end{array}$ & $\begin{array}{c}237.7^{* * *} \\
(30.54)\end{array}$ & $\begin{array}{c}268.0^{* * * *} \\
(36.02)\end{array}$ \\
\hline Evening shift & $\begin{array}{c}-254.7 * * * \\
(94.35)\end{array}$ & $\begin{array}{c}-386.7^{* * * *} \\
(111.5)\end{array}$ & $\begin{array}{c}-57.85 \\
(36.98)\end{array}$ & $\begin{array}{l}-71.50 \\
(65.02)\end{array}$ & $\begin{array}{l}-55.48 \\
(83.00)\end{array}$ & $\begin{array}{c}-41.12 \\
(68.52)\end{array}$ & $\begin{array}{l}67.62^{*} \\
(40.90)\end{array}$ & $\begin{array}{c}44.71 \\
(54.49)\end{array}$ \\
\hline Split shift & $\begin{array}{c}-93.80 * \\
(53.25)\end{array}$ & $\begin{array}{c}-162.8^{* * * *} \\
(32.59)\end{array}$ & $\begin{array}{c}-76.44^{* *} \\
(34.41)\end{array}$ & $\begin{array}{c}-256.8^{* * *} \\
(51.85)\end{array}$ & $\begin{array}{c}-60.23 \\
(60.02)\end{array}$ & $\begin{array}{c}-85.75^{\star *} \\
(40.66)\end{array}$ & $\begin{array}{c}-161.9 * * * \\
(41.43)\end{array}$ & $\begin{array}{c}-191.7 * * * \\
(39.81)\end{array}$ \\
\hline \multicolumn{9}{|c|}{ Spouse's work schedule } \\
\hline Unemployed & $\begin{array}{c}65.06^{* *} \\
(32.60)\end{array}$ & $\begin{array}{c}85.99 * * * * \\
(30.62)\end{array}$ & $\begin{array}{c}-78.94^{* * *} \\
(26.96)\end{array}$ & $\begin{array}{c}-222.5^{* * *} \\
(49.44)\end{array}$ & $\begin{array}{c}119.6^{* * *} \\
(43.05)\end{array}$ & $\begin{array}{l}69.29^{*} \\
(36.10)\end{array}$ & $\begin{array}{c}21.65 \\
(25.48)\end{array}$ & $\begin{array}{c}-39.71 \\
(28.72)\end{array}$ \\
\hline No working & $\begin{array}{c}178.5^{* * *} \\
(31.23)\end{array}$ & $\begin{array}{c}144.4^{* * * *} \\
(34.91)\end{array}$ & $\begin{array}{c}-95.68^{* * * *} \\
(29.01)\end{array}$ & $\begin{array}{l}-83.60^{*} \\
(44.19)\end{array}$ & $\begin{array}{c}166.5^{* * * *} \\
(44.05)\end{array}$ & $\begin{array}{c}26.37 \\
(41.90)\end{array}$ & $\begin{array}{c}-113.7^{* * *} \\
(29.90)\end{array}$ & $\begin{array}{c}-101.3^{* * * *} \\
(37.52)\end{array}$ \\
\hline Evening shift & $\begin{array}{c}-407.4^{* * *} \\
(106.6)\end{array}$ & $\begin{array}{c}-142.5^{* *} \\
(68.71)\end{array}$ & $\begin{array}{c}114.4^{* * *} \\
(33.21)\end{array}$ & $\begin{array}{c}206.9^{* * *} \\
(40.98)\end{array}$ & $\begin{array}{c}-2.393 \\
(70.06)\end{array}$ & $\begin{array}{l}-8.180 \\
(68.12)\end{array}$ & $\begin{array}{c}31.67 \\
(35.49)\end{array}$ & $\begin{array}{l}-84.38 \\
(54.08)\end{array}$ \\
\hline Split shift & $\begin{array}{c}-198.7^{* * *} \\
(35.72)\end{array}$ & $\begin{array}{c}-17.16 \\
(47.40)\end{array}$ & $\begin{array}{c}100.1^{* * *} \\
(18.23)\end{array}$ & $\begin{array}{c}84.41^{* *} \\
(35.68)\end{array}$ & $\begin{array}{c}-105.1^{* *} \\
(44.74)\end{array}$ & $\begin{array}{c}-50.09 \\
(52.19)\end{array}$ & $\begin{array}{l}45.18^{* *} \\
(20.85)\end{array}$ & $\begin{array}{c}-57.89 \\
(39.90)\end{array}$ \\
\hline \multicolumn{9}{|l|}{$\begin{array}{l}\text { Control variables } \\
O_{W n}\end{array}$} \\
\hline Part time $(<6 \mathrm{~h})$ & $\begin{array}{c}46.04 \\
(38.56)\end{array}$ & $\begin{array}{c}47.88 \\
(49.20)\end{array}$ & $\begin{array}{c}85.23^{* * *} \\
(24.37)\end{array}$ & $\begin{array}{c}-3.082 \\
(51.64)\end{array}$ & $\begin{array}{c}9.777 \\
(49.29)\end{array}$ & $\begin{array}{c}55.34 \\
(65.51)\end{array}$ & $\begin{array}{c}63.79^{* *} \\
(30.08)\end{array}$ & $\begin{array}{c}75.37 \\
(57.50)\end{array}$ \\
\hline Overwork (> $10 \mathrm{~h})$ & $\begin{array}{l}-588.8^{*} \\
(324.4)\end{array}$ & $\begin{array}{c}-198.9^{* * * *} \\
(58.22)\end{array}$ & $\begin{array}{c}6.885 \\
(126.1)\end{array}$ & $\begin{array}{c}-55.48 \\
(67.68)\end{array}$ & $\begin{array}{c}35.48 \\
(156.5)\end{array}$ & $\begin{array}{c}-121.9^{* *} \\
(61.77)\end{array}$ & $\begin{array}{c}-62.53 \\
(132.3)\end{array}$ & $\begin{array}{l}-114.9^{*} \\
(60.45)\end{array}$ \\
\hline Low secondary & $\begin{array}{l}-59.72 \\
(38.34)\end{array}$ & $\begin{array}{l}-13.20 \\
(34.02)\end{array}$ & $\begin{array}{c}10.35 \\
(26.67)\end{array}$ & $\begin{array}{l}-14.72 \\
(43.24)\end{array}$ & $\begin{array}{c}3.427 \\
(44.64)\end{array}$ & $\begin{array}{c}55.60 \\
(42.37)\end{array}$ & $\begin{array}{l}-4.165 \\
(25.34)\end{array}$ & $\begin{array}{l}-43.75 \\
(33.81)\end{array}$ \\
\hline High secondary & $\begin{array}{c}-17.96 \\
(36.80)\end{array}$ & $\begin{array}{c}-18.36 \\
(31.94)\end{array}$ & $\begin{array}{c}22.72 \\
(25.72)\end{array}$ & $\begin{array}{c}-14.61 \\
(39.28)\end{array}$ & $\begin{array}{c}-6.475 \\
(45.50)\end{array}$ & $\begin{array}{c}45.21 \\
(40.57)\end{array}$ & $\begin{array}{c}-10.84 \\
(25.23)\end{array}$ & $\begin{array}{c}-24.88 \\
(31.06)\end{array}$ \\
\hline College & $\begin{array}{l}-64.66 \\
(40.77)\end{array}$ & $\begin{array}{c}27.48 \\
(36.75)\end{array}$ & $\begin{array}{c}29.34 \\
(28.51)\end{array}$ & $\begin{array}{c}-22.80 \\
(44.59)\end{array}$ & $\begin{array}{c}58.02 \\
(50.18)\end{array}$ & $\begin{array}{c}21.58 \\
(47.14)\end{array}$ & $\begin{array}{c}-9.449 \\
(29.77)\end{array}$ & $\begin{array}{c}-15.97 \\
(37.56)\end{array}$ \\
\hline Age & $\begin{array}{l}-3.865^{*} \\
(2.138)\end{array}$ & $\begin{array}{l}-3.600 * \\
(1.850)\end{array}$ & $\begin{array}{l}-0.549 \\
(1.513)\end{array}$ & $\begin{array}{l}-3.007 \\
(2.182)\end{array}$ & $\begin{array}{l}5.658^{* *} \\
(2.602)\end{array}$ & $\begin{array}{c}0.626 \\
(2.160)\end{array}$ & $\begin{array}{c}6.232^{* * *} \\
(1.555)\end{array}$ & $\begin{array}{c}5.715^{* * *} \\
(1.821)\end{array}$ \\
\hline Spouse & & & & & & & & \\
\hline Part time & $\begin{array}{c}53.74 \\
(49.35)\end{array}$ & $\begin{array}{l}61.85^{*} \\
(35.68)\end{array}$ & $\begin{array}{c}-54.96 \\
(39.18)\end{array}$ & $\begin{array}{c}-80.27 * * \\
(35.33)\end{array}$ & $\begin{array}{c}48.77 \\
(72.27)\end{array}$ & $\begin{array}{c}-35.14 \\
(45.70)\end{array}$ & $\begin{array}{c}-25.69 \\
(44.79)\end{array}$ & $\begin{array}{c}1.964 \\
(35.75)\end{array}$ \\
\hline Overwork & $\begin{array}{c}-173.9^{* * *} \\
(61.50)\end{array}$ & $\begin{array}{c}-236.5 \\
(163.9)\end{array}$ & $\begin{array}{c}60.11^{* * *} \\
(18.94)\end{array}$ & $\begin{array}{l}120.3^{*} \\
(65.49)\end{array}$ & $\begin{array}{l}-7.444 \\
(58.51)\end{array}$ & $\begin{array}{c}42.73 \\
(131.9)\end{array}$ & $\begin{array}{l}39.69^{*} \\
(22.66)\end{array}$ & $\begin{array}{c}22.36 \\
(96.25)\end{array}$ \\
\hline Low secondary & $\begin{array}{c}11.72 \\
(36.62)\end{array}$ & $\begin{array}{l}-4.826 \\
(36.10)\end{array}$ & $\begin{array}{l}-22.68 \\
(23.61)\end{array}$ & $\begin{array}{c}29.59 \\
(54.62)\end{array}$ & $\begin{array}{l}-44.13 \\
(44.43)\end{array}$ & $\begin{array}{c}34.92 \\
(43.16)\end{array}$ & $\begin{array}{l}-17.09 \\
(24.88)\end{array}$ & $\begin{array}{l}-27.59 \\
(34.55)\end{array}$ \\
\hline High secondary & $\begin{array}{c}17.95 \\
(34.52)\end{array}$ & $\begin{array}{l}-4.365 \\
(35.53)\end{array}$ & $\begin{array}{c}-27.84 \\
(22.08)\end{array}$ & $\begin{array}{c}-24.19 \\
(49.46)\end{array}$ & $\begin{array}{c}-5.641 \\
(41.60)\end{array}$ & $\begin{array}{c}59.06 \\
(43.88)\end{array}$ & $\begin{array}{c}-8.866 \\
(23.53)\end{array}$ & $\begin{array}{c}-77.54^{* *} \\
(34.24)\end{array}$ \\
\hline College & $\begin{array}{c}45.27 \\
(39.39)\end{array}$ & $\begin{array}{l}-49.81 \\
(39.27)\end{array}$ & $\begin{array}{c}-67.90^{* * *} \\
(26.27)\end{array}$ & $\begin{array}{l}-49.33 \\
(49.80)\end{array}$ & $\begin{array}{l}-41.96 \\
(49.74)\end{array}$ & $\begin{array}{c}62.31 \\
(47.89)\end{array}$ & $\begin{array}{c}-5.136 \\
(28.59)\end{array}$ & $\begin{array}{l}-14.36 \\
(36.93)\end{array}$ \\
\hline Household & & & & & & & & \\
\hline Domestic service & $\begin{array}{c}2.185 \\
(34.74)\end{array}$ & $\begin{array}{l}-33.90 \\
(34.17)\end{array}$ & $\begin{array}{c}34.67 \\
(22.51)\end{array}$ & $\begin{array}{c}98.63^{* * * *} \\
(34.05)\end{array}$ & $\begin{array}{l}-11.17 \\
(45.58)\end{array}$ & $\begin{array}{c}12.40 \\
(41.30)\end{array}$ & $\begin{array}{l}46.54^{*} \\
(27.99)\end{array}$ & $\begin{array}{l}-16.78 \\
(37.33)\end{array}$ \\
\hline Child aged 0-2 & $\begin{array}{c}63.57^{* *} \\
(26.37)\end{array}$ & $\begin{array}{c}77.71^{* * * *} \\
(25.80)\end{array}$ & $\begin{array}{c}90.65^{* * *} \\
(15.60)\end{array}$ & $\begin{array}{c}39.95 \\
(26.52)\end{array}$ & $\begin{array}{c}-87.13^{* *} \\
(43.59)\end{array}$ & $\begin{array}{c}-107.2^{* * *} \\
(39.97)\end{array}$ & $\begin{array}{c}-99.01 * * * \\
(26.57)\end{array}$ & $\begin{array}{c}-14.94 \\
(31.53)\end{array}$ \\
\hline \# children $0-9$ & $\begin{array}{c}5.897 \\
(16.17)\end{array}$ & $\begin{array}{c}-5.837 \\
(15.48)\end{array}$ & $\begin{array}{c}31.61 * * * \\
(10.20)\end{array}$ & $\begin{array}{c}16.17 \\
(19.33)\end{array}$ & $\begin{array}{c}-56.13^{* *} \\
(25.29)\end{array}$ & $\begin{array}{c}-42.95^{* *} \\
(21.50)\end{array}$ & $\begin{array}{c}-36.97 * * * \\
(13.96)\end{array}$ & $\begin{array}{l}-25.14 \\
(17.10)\end{array}$ \\
\hline \# children $10-17$ & $\begin{array}{c}-38.52 * \\
(19.73)\end{array}$ & $\begin{array}{c}-23.14 \\
(17.89)\end{array}$ & $\begin{array}{c}-70.40^{* * *} \\
(15.46)\end{array}$ & $\begin{array}{c}-76.93^{* * *} \\
(29.20)\end{array}$ & $\begin{array}{c}-35.74 \\
(23.58)\end{array}$ & $\begin{array}{c}-18.50 \\
(21.35)\end{array}$ & $\begin{array}{l}21.44^{*} \\
(12.41)\end{array}$ & $\begin{array}{c}12.65 \\
(17.05)\end{array}$ \\
\hline Constant & $\begin{array}{c}124.2 \\
(101.1)\end{array}$ & $\begin{array}{c}132.8 \\
(96.19)\end{array}$ & $\begin{array}{c}-45.72 \\
(69.75)\end{array}$ & $\begin{array}{c}149.7 \\
(106.9)\end{array}$ & $\begin{array}{c}-340.3^{* * *} \\
(150.3)\end{array}$ & $\begin{array}{c}-189.8 \\
(129.8)\end{array}$ & $\begin{array}{c}-289.2^{* * *} \\
(83.02)\end{array}$ & $\begin{array}{l}-195.1^{*} \\
(101.8)\end{array}$ \\
\hline
\end{tabular}


Table 2 (continued): Double Hurdle model estimation results.

\begin{tabular}{|c|c|c|c|c|c|c|c|c|}
\hline & \multicolumn{2}{|c|}{ Family time } & \multicolumn{2}{|c|}{ Children time } & \multicolumn{2}{|c|}{ Partner time } & \multicolumn{2}{|c|}{ Non family time } \\
\hline & Women & Men & Women & Men & Women & Men & Women & Men \\
\hline \multicolumn{9}{|c|}{ Participation decision } \\
\hline Child aged 0-9 & $\begin{array}{c}0.516^{* * *} \\
(0.0832)\end{array}$ & $\begin{array}{c}0.622^{* * *} \\
(0.0833)\end{array}$ & $\begin{array}{c}2.708^{* * *} \\
(0.127)\end{array}$ & $\begin{array}{c}1.864^{* * *} \\
(0.126)\end{array}$ & $\begin{array}{c}-0.0427 \\
(0.0796)\end{array}$ & $\begin{array}{c}-0.104 \\
(0.0791)\end{array}$ & $\begin{array}{c}-0.477 * * * \\
(0.103)\end{array}$ & $\begin{array}{l}-0.226^{* *} \\
(0.0885)\end{array}$ \\
\hline Unemployed & $\begin{array}{c}0.105 \\
(0.104)\end{array}$ & $\begin{array}{c}0.114 \\
(0.137)\end{array}$ & $\begin{array}{c}0.395^{* * *} \\
(0.125)\end{array}$ & $\begin{array}{c}0.342^{* *} \\
(0.146)\end{array}$ & $\begin{array}{c}0.111 \\
(0.0961)\end{array}$ & $\begin{array}{l}0.0690 \\
(0.127)\end{array}$ & $\begin{array}{c}0.179 \\
(0.117)\end{array}$ & $\begin{array}{c}0.626^{* * *} \\
(0.170)\end{array}$ \\
\hline No working & $\begin{array}{c}0.186 \\
(0.138)\end{array}$ & $\begin{array}{l}0.271^{*} \\
(0.148)\end{array}$ & $\begin{array}{c}-0.00591 \\
(0.154)\end{array}$ & $\begin{array}{c}-0.00474 \\
(0.143)\end{array}$ & $\begin{array}{c}-0.0226 \\
(0.123)\end{array}$ & $\begin{array}{c}0.395^{* * * *} \\
(0.138)\end{array}$ & $\begin{array}{c}-0.145 \\
(0.141)\end{array}$ & $\begin{array}{l}0.0507 \\
(0.144)\end{array}$ \\
\hline Evening shift & $\begin{array}{c}-0.615^{* * *} \\
(0.186)\end{array}$ & $\begin{array}{c}-0.704^{* * *} \\
(0.190)\end{array}$ & $\begin{array}{c}0.672^{* * *} \\
(0.257)\end{array}$ & $\begin{array}{c}-0.103 \\
(0.225)\end{array}$ & $\begin{array}{c}-0.105 \\
(0.185)\end{array}$ & $\begin{array}{c}-0.0905 \\
(0.190)\end{array}$ & $\begin{array}{c}0.281 \\
(0.244)\end{array}$ & $\begin{array}{l}0.0202 \\
(0.215)\end{array}$ \\
\hline Split shift & $\begin{array}{c}-0.266^{* *} \\
(0.130)\end{array}$ & $\begin{array}{l}-0.0865 \\
(0.101)\end{array}$ & $\begin{array}{c}-0.164 \\
(0.167)\end{array}$ & $\begin{array}{c}-0.454^{* * *} \\
(0.108)\end{array}$ & $\begin{array}{l}-0.208^{*} \\
(0.126)\end{array}$ & $\begin{array}{c}-0.255^{* * *} \\
(0.0928)\end{array}$ & $\begin{array}{c}-0.134 \\
(0.148)\end{array}$ & $\begin{array}{c}-0.370^{* * *} \\
(0.100)\end{array}$ \\
\hline Low secondary & $\begin{array}{c}0.171 \\
(0.128)\end{array}$ & $\begin{array}{c}0.153 \\
(0.125)\end{array}$ & $\begin{array}{c}0.263 \\
(0.169)\end{array}$ & $\begin{array}{c}0.348^{* *} \\
(0.150)\end{array}$ & $\begin{array}{c}0.294^{* *} \\
(0.123)\end{array}$ & $\begin{array}{c}0.267^{* *} \\
(0.119)\end{array}$ & $\begin{array}{c}0.222 \\
(0.158)\end{array}$ & $\begin{array}{c}-0.0200 \\
(0.133)\end{array}$ \\
\hline High secondary & $\begin{array}{c}0.261^{* *} \\
(0.123)\end{array}$ & $\begin{array}{c}0.293^{* *} \\
(0.118)\end{array}$ & $\begin{array}{c}0.174 \\
(0.157)\end{array}$ & $\begin{array}{c}0.606^{* * * *} \\
(0.138)\end{array}$ & $\begin{array}{c}0.290^{* *} \\
(0.117)\end{array}$ & $\begin{array}{c}0.228^{* *} \\
(0.110)\end{array}$ & $\begin{array}{c}-0.0113 \\
(0.143)\end{array}$ & $\begin{array}{l}0.0858 \\
(0.124)\end{array}$ \\
\hline College & $\begin{array}{c}0.287 * * \\
(0.131)\end{array}$ & $\begin{array}{c}0.268^{* *} \\
(0.131)\end{array}$ & $\begin{array}{c}0.484^{* * *} \\
(0.166)\end{array}$ & $\begin{array}{c}0.730 * * * \\
(0.150)\end{array}$ & $\begin{array}{c}0.409 * * * \\
(0.124)\end{array}$ & $\begin{array}{c}0.337^{* * * *} \\
(0.122)\end{array}$ & $\begin{array}{c}0.121 \\
(0.151)\end{array}$ & $\begin{array}{c}0.164 \\
(0.136)\end{array}$ \\
\hline Married & $\begin{array}{c}0.181 \\
(0.164)\end{array}$ & $\begin{array}{c}0.184 \\
(0.160)\end{array}$ & $\begin{array}{c}-0.150 \\
(0.188)\end{array}$ & $\begin{array}{c}-0.131 \\
(0.157)\end{array}$ & $\begin{array}{c}0.323^{* *} \\
(0.151)\end{array}$ & $\begin{array}{c}0.235 \\
(0.145)\end{array}$ & $\begin{array}{c}0.105 \\
(0.173)\end{array}$ & $\begin{array}{l}0.0817 \\
(0.160)\end{array}$ \\
\hline Constant & $\begin{array}{l}0.0165 \\
(0.204)\end{array}$ & $\begin{array}{l}0.0128 \\
(0.198)\end{array}$ & $\begin{array}{c}-2.097 * * * \\
(0.262)\end{array}$ & $\begin{array}{c}-2.115^{* * *} \\
(0.234)\end{array}$ & $\begin{array}{c}-0.134 \\
(0.191)\end{array}$ & $\begin{array}{c}0.104 \\
(0.184)\end{array}$ & $\begin{array}{c}1.175^{* * *} \\
(0.227)\end{array}$ & $\begin{array}{c}0.891 * * * \\
(0.203)\end{array}$ \\
\hline LNSIGMA $(\rho)$ & & & & & & & & \\
\hline Constant & $\begin{array}{l}5.182^{* * * *} \\
(0.0604)\end{array}$ & $\begin{array}{c}5.176 * * * \\
(0.0582)\end{array}$ & $\begin{array}{l}4.881^{* * *} \\
(0.0422)\end{array}$ & $\begin{array}{c}4.897^{* * * *} \\
(0.0849)\end{array}$ & $\begin{array}{l}5.175^{* * *} \\
(0.0930)\end{array}$ & $\begin{array}{c}5.161^{* * *} \\
(0.0839)\end{array}$ & $\begin{array}{l}5.117 * * * \\
(0.0424)\end{array}$ & $\begin{array}{l}5.252^{* * *} \\
(0.0534)\end{array}$ \\
\hline Observations & 1,201 & 1,201 & 1,201 & 1,201 & 1,201 & 1,201 & 1,201 & 1,201 \\
\hline & 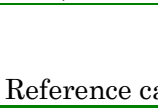 & . & $\begin{array}{l}\text { tandard er } \\
* * \mathrm{p}<0.01 \\
\text { york, full-. }\end{array}$ & $\begin{array}{l}\text { n paren } \\
=0.05,{ }^{*} \\
\text { work }(6-\end{array}$ & - & . & & \\
\hline
\end{tabular}

Source: Own elaboration

Regarding the quantity decision, we focus on the effect of own work schedule and that of the spouse's one. We have also included some other control variables of the individual and the partner such as, hours of work, education and age. Finally, we have also controlled for some household variables, such as, outsourcing domestic work and number and age of children. 
Being unemployed or not working the reference day increases the time spent in all the time uses. Working an evening shift ${ }^{7}$ decreases family time and, in the case of women, increases non-family time. When analyzing the effect of the split shift, we find that working a split shift significantly decreases family, children, partner and non-family time.

Moving to the effect of the spouse's work schedule, we find that when the spouse works an evening shift the individual spends less family time, as the presence of the spouse is needed in this time-use. However the time spent by the individual with children significantly increases. It seems that individual makes up for the time that his/her spouse cannot spend with children. When the spouse is working a split shift, the individual will also spend more time with children regardless of gender. On the other hand, if the husband works a split shift our results suggest that women spend more non-family time but we do not find a significant effect on men' non-family time if it is the wife who works a split shift.

Regarding other control variables included, we find an increase of children time and non-family time of women when they work part time. A decrease of family time, partner time and non-family time of men is found when they work more than 10 hours. We do not find a significant effect of education on the amount of family, children, partner and non-family time, but we should remember that we found a significant effect on the participation decision. So we could conclude that the level of education affects the decision of becoming a participant on each time-use, but once you are participating then education does not significantly affect the amount of time spent on each time-use. Older people spend more minutes on non-family time.

As for the effect of the spouse' characteristics we find that if the wife is working less than 6 hours her husband spends less time with children. We also find that if the husband works more than 10 hours his wife spends more time with children. As regards education levels of the spouse, we find a significant negative effect on women's children time if their husbands have college education. Finally we have the effects of the household control variables. When the household has housekeeping service men spend more time with their children and women spend

\footnotetext{
7 Given that work schedule is not really a choice by the employee but given by the employer we do not think that the effect of working schedules may reflect special characteristics of workers with different work-schedules.
} 
more time in non-family activities. When a child under 2 years of age is present family time increases and partner time decreases for both men and women. Additionally, in the case of women children time increases and non-family time will decrease. We do not find a significant effect of this variable on children time and non-family time for men. When the number of children of 0-9 years of age increases then partner time decreases and, in the case of women, children time increases and nonfamily time decreases. As children age, as expected, children time decreases and the effect on the other time-uses diminishes for women or vanishes for men.

\section{Conclusion}

Our study contributes to the literature by using the most recent Spanish Time Use Survey (STUS) data of 2009-2010 to study the effect that different work schedules have on the time spent in family, with children and with the partner. Gracia and Kalmijn (2016) did a similar study using data from the STUS 2002-2003. The survey has been improved since 2002. The STUS of 2002-2003 does not allow to separate the activities that the individuals do with their partner from those they do with their children older than 9 years of age. For this reason, they only consider those families with children under 10 years old, dropping the families where at least one child above the age of 9 was present. In the newest version of the data we have that information and we can include all the families with at least one child below 18 years of age in our final sample. We believe this provides evidence that can be expanded to a larger part of the population. The previous results were only for families where young children were present, whereas now we have found evidence for families with children of all ages.

Another difference from Gracia and Kalmijn (2016) is the estimation method used. They used a seemingly unrelated regression model to study the link between work schedules and time uses. We, however, use a double hurdle model that allows us to take into account the clustering of a large proportion of observations at zero and deal with both the incidence and the intensity of spending time in a particular time use.

Our study has three main findings. First, our results show that the split shift has a significant negative effect on family time and parent child time, two activities that improve the relationship among family members and improve the wellbeing of children. Therefore, the split 
shift is not only a family-unfriendly work schedule but also strongly child-unfriendly.

Second, we find that individuals engage significantly more in parent-child activities with children under 10 years old when their spouse is working a split shift or evening shift, that is, a nonstandard work schedule. These results are consistent with the idea that spouses decisions are taken simultaneously, depending on his/her spouse' work schedule the individual decides his/her amount of time spent with children.

Third, we find that the negative effect that working an evening or split shift has on parent-child time is smaller for women than for men. The opposite is observed with non-family time.

With these results we could conclude that this study has important public policy implications. The split shift is making more difficult for dual-earner couples to have a work-life balance. This could be one of the reasons explaining the low female labor force participation rates in Spain in comparison with other European countries. Women could decide to accept a job with a standard work schedule if their spouses are already working a split shift. If women received a job offer with a split work schedule, the couple would need someone to be with their children after school if women accepted the offer, as none of the spouses would be at home when the children arrived from school. This makes women to have less job opportunities. Moreover, when studying the private sector, in some cases, women will only apply for the less skilled jobs as, in higher positions, work schedules, normally, are worst for a work-life balance as working days are longer.

Making work schedules more compatible with school schedules might be a way of facilitating the conciliation of the labor and family life. In fact, one of the issues during the previous political campaign in Spain was the benefits that ending the working day before six o'clock could have on this conciliation. Providing evidence of the negative effects of working later than 6 p.m. on the time spent with the family could give the motives to undertake the adequate policy changes to improve the work-family balance. This policy changes might also have a positive effect on the decision of having more children per women, as in the last 40 years there have been an important decrease in the fertility rate of western countries. 


\section{References}

Amuedo-Dorantes, Catalina and Sara De La Rica. (2009). "The Timing of Work and WorkFamily Conflicts in Spain: Who Has a Split Work Schedule and Why?" IZA Discussion Paper No. 4542.

Becker, Gary. S. (1965). "A Theory of the Allocation of Time". The Economic Journal, 493517.

Bianchi, Suzanne M., John P. Robinson and Melissa A. Milke. (2006). "The changing rhythms of American family life". Russell Sage Foundation.

Blundell, Richard and Costas Meghir. (1987). "Bivariate alternatives to the Tobit model". Journal of Econometrics, 34 (1-2), 179-200.

Burda, Michael, Daniel Hamermesh, and Philippe Weil (2012): "Total work and gender: facts and possible explanations." Journal of Population Economics

Cragg, John G. (1971). "Some statistical models for limited dependent variables with application to the demand for durable goods". Econometrica, 39 (5), 829-844.

Dew, Jeffrey. (2009). "Has the Marital Time Cost of Parenting Changed Over Time?" Social Forces, Volume 88, Issue 2, 519-541, https://doi.org/10.1353/sof.0.0273

Foster, G. and Kalenkoski, C. M. (2013). "Tobit or OLS? An empirical evaluation under different diary window lengths". Applied Economics 45 (20), 2994-3010.

Gershuny, Jonathan. (2003). "Changing times: Work and leisure in postindustrial society". Oxford University Press. Oxford, UK

Gimenez-Nadal, J. Ignacio and Jose Alberto Molina. (2013). "Parents' education as a determinant of educational childcare time". Journal of Population Economics, 26 (2), 719749 .

Gracia, Pablo and Matthijs Kalmijn. (2016). "Parents' Family Time and Work Schedules: The Split-Shift Schedule in Spain”. Journal of Marriage and Family, 78 (2), 401-415.

Jacobs, Jerry A. and Kathleen Gerson. (2005). "The time divide: Work, family, and gender inequality". Harvard University Press.

Kalenkoski C, Ribar D, Stratton L (2009). "The influence of wages on parents' allocations of time to child care and market work in the United Kingdom" Journal of Population Economics 22(2):399-419

Lesnard, Laurent. (2008). "Off-Scheduling within Dual-Earner Couples: An Unequal and Negative Externality for Family Time”. American Journal of Sociology, 114 (2), 447-490.

Li, Jianghong, Sarah E. Johnson, Wen-Jui Han, Sonia Andrews, Garth Kendall, Lyndall Strazdins and Alfred Dockery (2014). "Parents' nonstandard work schedules and child well- 
being: A critical review of the literature". The journal of primary prevention, 35 (1), 53-73.

Mattingly, Marybeth J. and Liana C. Sayer. (2006). "Under pressure: Gender differences in the relationship between free time and feeling rushed". Journal of Marriage and Family, 68(1), 205-221.

Newman, Carol, Maeve Henchion and Alan Matthews. (2003). "A double-hurdle model of Irish household expenditure on prepared meals". Applied Economics, 35 (9), 1053-1061.

Presser, Harriet B. (2003). "Working in a 24/7 Economy. Challenges for American Families”. Russell Sage Foundation. New York, 394-410.

Roeters, Anne, Tanja Van Der Lippe and Esther S. Kluwer. (2010). "Work Characteristics and Parent-Child Relationship Quality: The Mediating Role of Temporal Involvement". Journal of Marriage and Family, 72 (5), 1317-1328.

SanMartin, Olga R. (13th of November 2014). "La jornada intensiva ya es mayoritaria en los colegios públicos de 12 comunidades autónomas". El mundo. Retrieved from http://www.elmundo.es/

Stewart, J. (2013). “Tobit or not tobit?” Journal of Economic and Social Measurement, 38 (3), 263-290.

Wight, Vanessa R., Sara B. Raley and Suzanne M. Bianchi. (2008). "Time for children, one's spouse and oneself among parents who work nonstandard hours". Social Forces, 87 (1), 243-271.

C) Revista de Economía Laboral 